\title{
Gestational Outcomes in Patients with Severe Maternal Morbidity Caused by Hypertensive Syndromes
}

\section{Resultados gestacionais em pacientes com morbidade materna grave causada por síndromes hipertensivas}

\author{
Daisy de Lucena Feitosa Lins Pinheiro ${ }^{10}$ Francisco Edson de Lucena Feitosa ${ }^{1(0)}$ \\ Edward Araujo Júnior ${ }^{2,3(0)}$ Francisco Herlânio Costa Carvalho ${ }^{10}$
}

${ }^{1}$ Department of Obstetrics and Gynecology, Faculdade de Medicina, Universidade Federal do Ceará, Fortaleza, CE, Brazil

2 Department of Obstetrics, Escola Paulista de Medicina, Universidade Federal de São Paulo, São Paulo, SP, Brazil

${ }^{3}$ Medical Course, Universidade Municipal de São Caetano do Sul, São Paulo, SP, Brazil

\author{
Address for correspondence Edward Araujo Júnior, PhD, \\ Departmento de Obstetrícia, Escola Paulista de Medicina, \\ Universidade Federal de São Paulo, Rua Napoleão de Barros, 875, Vila \\ Clementino, São Paulo, SP, 04024-002, Brazil \\ (e-mail: araujojred@terra.com.br).
}

Rev Bras Ginecol Obstet 2020;@42(2):74-80.

received

May 24, 2019

accepted

November 22, 2019
Purpose To evaluate the impact of the presence of criteria for severe maternal morbidity and maternal near miss associated with hypertensive disorders on maternal and perinatal outcomes in a maternity school.

Methods The present is a sub-analysis of a larger study involving 27 centers in Brazil that estimated the prevalence of serious maternal morbidity and near miss. It is an analytical and cross-sectional study with a quantitative approach, involving 928 women who were cared for at Maternidade Escola Assis Chateaubriand (MEAC, in Portuguese), Universidade Federal do Ceará (UFC, in Portuguese), from July 2009 to June 2010. The women were diagnosed with near miss according to the World Health Organization (WHO) criteria. The sample was divided into 2 groups: patients with $(n=827)$ and without hypertension $(n=101)$. The results were considered statistically significant when $p<0.05$. The Pearson chi-squared and Fisher Exact tests were used for the categorical variables, and the Mann-Whitney $U$ test was used for the continuous variables.

Results In total, 51 participants with maternal near miss criteria were identified, and 36 of them had hypertensive disorders. Of these, 5 died and were obviously excluded from the near miss final group. In contrast, we observed 867 cases with non-near miss maternal morbidity criteria. During this period, there were 4,617 live births (LBs) in the institution that was studied.

Conclusion In the severe morbidity/maternal near miss population, the presence of hypertensive complications was prevalent, constituting a risk factor for both the mother and the fetus. disorders

DOI https://doi.org/ 10.1055/s-0040-1701464. ISSN 0100-7203.
Copyright (e 2020 by Thieme Revinter

Publicações Ltda, Rio de Janeiro, Brazil
License terms

(c) (1) 


\section{Resumo}

\section{Palavras-chave}

- complicações na gestação

- morbidade materna

- gestação de alto risco

- distúrbios hipertensivos
Objetivo Avaliar o impacto da presença de critérios de morbidade materna grave e potencial evento adverso materno associados a distúrbios hipertensivos nos desfechos maternos e perinatais em uma maternidade escola.

Métodos Trata-se de uma subanálise de um estudo maior, envolvendo 27 centros, que estimou a prevalência de morbidade materna grave e potencial evento adverso no Brasil. Realizou-se um estudo analítico e transversal, com abordagem quantitativa, envolvendo 928 mulheres atendidas na Maternidade Escola Assis Chateaubriand (MEAC), na Universidade Federal do Ceará (UFC), no período de julho de 2009 a junho de 2010, diagnosticadas com potencial evento adverso de acordo com os critérios da Organização Mundial da Saúde (OMS). A amostra foi dividida em dois grupos: pacientes com $(n=827)$ e sem hipertensão $(n=101)$. Os resultados foram considerados estatisticamente significativos quando $p<0,05$. O teste do Qui-quadrado de Pearson e o teste exato de Fisher foram usados para as variáveis categóricas, e o teste $U$ de Mann-Whitney, para as variáveis contínuas.

Resultados Foram identificados 51 participantes com critérios de potencial evento adverso materno, sendo 36 mulheres com distúrbios hipertensivos. Destas, 5 morreram e foram obviamente excluídas do grupo final do potencial evento adverso. Foram observados 867 casos com critérios de morbidade materna que não caracterizavam potencial evento adverso. Nesse período, houve 4.617 nascidos vivos (NVs) na instituição estudada.

Conclusão Na população com morbidade grave/potencial evento adversomaterno, a presença de complicações hipertensivas é prevalente, constituindo fator de risco para o binômio materno-fetal.

\section{Introduction}

Arterial hypertension is a severe public health problem, and it is a frequent cause of gestational complications worldwide. ${ }^{1-3}$ Hypertensive disorders have the potential to increase other clinical complications 3- to 25 -fold, which may lead to death. ${ }^{4,5}$

Hypertensive disorders are responsible for $\sim 50$ thousand cases of global maternal deaths per year, and they are the main cause of maternal death in Latin America and the Caribbean. Estimates indicate that this problem represents a quarter of the total number of these deaths. ${ }^{6,7}$ In Brazil, it is the primary cause of direct maternal death, with a prevalence of $37 \%$ of these cases; additionally, the ratio is higher in the Northern and Northeastern regions of Brazil compared with the Southeastern, Southern and Midwestern regions. ${ }^{7-9}$

Studying maternal death is a step to improve the obstetrical care process, as it can signal potential problems in the health system and enable the development of strategies to improve the quality of maternal assistance. ${ }^{10}$ However, an important piece of data to increase the information related to maternal health is the identification and analysis of cases involving women who survived severe complications during pregnancy, parturition and the puerperium - which are called maternal near miss -, because they allow us to understand the aspects that the survivors have in common with those who died from these complications, facilitating the gathering of information. The patients themselves are sources of information about what truly happened during their medical care, reporting potential difficulties with referrals and delayed care. ${ }^{11,12}$
Near misses occur more often than maternal death. The identification and knowledge of these cases enables the development of strategies to reduce the number of maternal deaths for reasons that could be avoided. ${ }^{13}$

The present study aimed to evaluate the impact of the presence of criteria for severe maternal morbidity and maternal near miss associated with hypertensive disorders on maternal and perinatal outcomes in a maternity school that is a reference in tertiary care.

\section{Methods}

The present is an analytical and cross-sectional study with a quantitative approach, involving 928 women who were cared for at Maternidade Escola Assis Chateaubriand (MEAC, in Portuguese), Universidade Federal do Ceará (UFC, in Portuguese), from July 2009 to June 2010; the patients were diagnosed with near miss according to the World Health Organization $(\mathrm{WHO})^{14}$ criteria and/or the non-near miss maternal morbidity criteria of the Brazilian Ministry of Health. Severe morbidity cases due to abortion were excluded, cases in which the parturition did not occur in the institution, as well as cases in which the medical records were unavailable for consulting. This is a sub-analysis of a larger study involving 27 centers that estimated the prevalence of severe maternal morbidity and near miss in Brazil. ${ }^{15}$

The variables that were studied include: age, schooling, race/ethnicity, marital status, number of pregnancies, parity, previous abortion, previous cesarean section, process of parturition, preexistent clinical conditions, perinatal outcome 
(birth weight, Apgar score and death) and maternal outcome (severe maternal morbidity, including near miss and maternal death).

The sample was divided in two groups: patients with $(\mathrm{n}=827)$ and without hypertension $(\mathrm{n}=101)$. Out of the 827 participants who had a diagnosis of hypertensive syndrome, 49 had chronic hypertension, 20 had preeclampsia without signs of severity, 616 had preeclampsia with signs of severity, 60 had eclampsia, and 82 had hemolysis, elevated liver enzymes, and a low platelet count (HELLP) syndrome. Chronic hypertension was considered when the hypertension diagnosis $(\geq 140$ $\times 90 \mathrm{~mm} \mathrm{Hg}$ ) occurred before the 20th gestational week in the absence of proteinuria. Preeclampsia was considered when hypertension was identified after the 20th gestational week in the presence of proteinuria ( $\geq 300 \mathrm{mg}$ of protein in 24-hour urine or in labstix isolated samples with two crosses in a single episode or two identifications of a cross). Preeclampsia was classified as severe when the hypertension was $\geq 160 \times 100$ $\mathrm{mm} \mathrm{Hg}$, creatinine $\geq 1.2 \mathrm{mg} / \mathrm{dl}$, oliguria $(<400 \mathrm{ml}$ within 24 hours), or signs of impending eclampsia were observed (nausea, vomiting, turbidity or visual scotomas, occipital headache and epigastralgia). The diagnostic criteria used at the time were ratified by the International Society for The Study of Hypertension in Pregnancy (ISSHP) in 2014. ${ }^{16}$

For the statistical analysis, the International Business Machines Statistical Package for the Social Sciences (IBM SPSS Statistics for Windows, IBM Corp., Armonk, NY, US) software, version 22.0 , was used. The results were considered statistically significant when $p<0.05$. The Pearson chisquared and the Fisher exact tests were used for the categorical variables, and the Mann-Whitney $U$ test was used for the continuous variables.

The project was approved by the Ethics in Research Committee of UFC under number 1.783.162. The free and informed consent forms of the women were not obtained individually. The information of interest was gathered from medical records without identifying the patient's name; instead, the record number was used.

\section{Results}

The sociodemographic data of the cases classified as severe maternal morbidity with or without hypertension are shown in - Table 1. No difference between the groups was observed, except regarding race/ethnicity, with three patients selfdeclaring as white, and 925 self-declaring as non-white. Most women did not have partners. Additionally, the women were between 20 and 34 years old, and had more than 8 years of schooling.

In relation to the obstetrical characteristics, there was a higher number of primiparous women $(p=0.005)$ and subjects without previous abortions $(p=0.024)$ in the group of patients with hypertension ( - Table 1 ). Most parturitions with hypertensive complications occurred through cesarean section: 635. Among the severe maternal morbidity indicators, there were 110 intensive care unit (ICU) admissions, 80 blood transfusions ( 29 requiring at least 5 units of packed red blood cells), 42 hospitalizations for more than 7 days post-
Table 1 Epidemiological and clinical characteristics of the patients identified as cases of severe maternal morbidity with and without hypertension

\begin{tabular}{|c|c|c|c|}
\hline \multicolumn{4}{|l|}{ Hypertension } \\
\hline Variables & $\begin{array}{l}\text { Yes } \\
\text { n (\%) }\end{array}$ & $\begin{array}{l}\text { No } \\
\text { n (\%) }\end{array}$ & $p$-value \\
\hline Age (years) & & & $0.061^{*}$ \\
\hline $10-19$ & $178(21.5)$ & $13(12.9)$ & \\
\hline $20-34$ & $511(61.8)$ & $74(73.3)$ & \\
\hline 35 or older & $138(16.7)$ & $14(13.9)$ & \\
\hline Schooling & & & $0.081^{*}$ \\
\hline$>8$ years & $450(63)$ & $31(51.7)$ & \\
\hline$\leq 8$ years & $264(37)$ & $29(48.3)$ & \\
\hline Marital status & & & $0.603^{*}$ \\
\hline With a partner & $194(27.4)$ & $18(30.5)$ & \\
\hline Without a partner & $515(72.6)$ & $41(69.5)$ & \\
\hline Pregnancies & & & $0.005^{*}$ \\
\hline 1 & $403(48.7)$ & $32(31.7)$ & \\
\hline $2-3$ & $294(35.6)$ & $47(46.5)$ & \\
\hline$>3$ & $130(15.7)$ & $22(21.8)$ & \\
\hline Births & & & $0.336^{*}$ \\
\hline 1 & $195(53.1)$ & $32(53.3)$ & \\
\hline $2-3$ & $138(37.6)$ & $19(31.7)$ & \\
\hline$>3$ & $34(9.3)$ & $9(15)$ & \\
\hline $\begin{array}{l}\text { Previous cesarean } \\
\text { sections }\end{array}$ & & & $0.832^{*}$ \\
\hline 1 & $133(70.4)$ & $15(68.2)$ & \\
\hline$\geq 2$ & $56(29.6)$ & $7(31.8)$ & \\
\hline Abortions & & & $0.024^{*}$ \\
\hline None & $639(77.5)$ & $68(67.3)$ & \\
\hline$>1$ & $186(22.5)$ & $33(32.7)$ & \\
\hline Number of live births & & & $0.023^{*}$ \\
\hline 1 & $197(55.3)$ & $29(50)$ & \\
\hline $2-3$ & $119(33.4)$ & 15 (25.9) & \\
\hline$>3$ & $40(11.2)$ & $14(24.1)$ & \\
\hline $\begin{array}{l}\text { Years since the } \\
\text { last birth }\end{array}$ & & & $0.436^{*}$ \\
\hline 1 & $4(6.7)$ & $18(5)$ & \\
\hline $2-3$ & 7 (11.7) & $65(18.1)$ & \\
\hline$>3$ & $49(81.7)$ & 276 (76.9) & \\
\hline Prenatal care visits & & & $0.092^{*}$ \\
\hline$<6$ & $236(44.4)$ & $32(56.1)$ & \\
\hline$\geq 6$ & $295(55.6)$ & 25 (43.9) & \\
\hline
\end{tabular}

Note: *Pearson chi-squared test.

partum, 33 hysterectomies, and 17 intubations (unrelated to anesthesia), with no significant difference between the groups with and without hypertension. Among the cases with potentially life-threatening conditions ( $n=142$, some 
Table 2 Maternal near miss and death among the patients identified with severe maternal morbidity associated or not with hypertensive syndromes

\begin{tabular}{llll}
\hline Hypertension & & & \\
\hline Variables & $\begin{array}{l}\text { Yes } \\
\mathbf{n}(\%)\end{array}$ & $\begin{array}{l}\text { No } \\
\mathbf{n}(\%)\end{array}$ & p-value \\
\hline $\begin{array}{llll}\text { Near miss criteria } \\
\text { Yes }\end{array}$ & $36(71)$ & $15(29)$ & $<0,0007^{*}$ \\
No & $86(91)$ & $81(9)$ & \\
Maternal death & & & $<0.001^{*}$ \\
Yes & $5(0.6)$ & $5(4.9)$ & \\
No & $822(99.4)$ & $96(95.1)$ & \\
\hline
\end{tabular}

Note: *Pearson chi-squared test.

patients had more than 1 condition), the following were highlighted: premature detachment of the placenta $(n=44)$; placenta accreta/percreta (10); shock (24); respiratory failure (23); sepsis (23); postpartum hemorrhage (23); endometritis (6); acute pulmonary edema (2); ectopic pregnancy (9); and uterine rupture (1), with no significant difference between the groups with and without hypertension. Magnesium sulfate was used in 682 cases, all of which were in the hypertensive group. In total, 51 participants with maternal near miss criteria were identified, 36 of whom were women with hypertensive disorders. From this group, 5 died; therefore, they were obviously excluded from the final near miss group. We observed 867 cases of non-near miss maternal morbidity criteria. During this period, there were 4,617 live births (LBs) in the institution that was studied, with a maternal near miss ratio of 55.55/1,000 LBs, a non-near miss maternal morbidity ratio of $190.6 / 1,000$ LBs, and a maternal morbidity ratio of $238.2 / 1,000$ LBs. We observed

Table 3 Perinatal outcomes of women identified with severe maternal morbidity criteria with and without hypertensive syndromes

\begin{tabular}{llll}
\hline Hypertension & & & \\
\hline Variables & $\begin{array}{l}\text { Yes } \\
\mathbf{n}(\%)\end{array}$ & $\begin{array}{l}\text { No } \\
\mathbf{n}(\%)\end{array}$ & p-value \\
\hline $\begin{array}{l}\text { Perinatal death } \\
\quad \text { Yes }\end{array}$ & $41(5)$ & $20(19.8)$ & $<0.001^{*}$ \\
$\quad$ No & $786(95)$ & $81(80.2)$ & \\
$\begin{array}{l}\text { Average birth } \\
\text { weight }(g)\end{array}$ & $2,723.6 \pm 837.7$ & $2,848.1 \pm 742.3$ & $0.569^{* *}$ \\
$\begin{array}{l}\text { (mean } \pm S D) \\
\text { Low birth }\end{array}$ & & & \\
weight & & & $0.817^{*}$ \\
$\quad$ Yes & $278(36.8)$ & $26(38.2)$ & \\
$\quad$ No & $477(63.2)$ & $42(61.8)$ & \\
Prematurity & & & $0.759^{*}$ \\
$\quad<37$ weeks & $281(37.2)$ & $27(39.7)$ & \\
$\geq 37$ weeks & $474(62.8$ & $41(60.3)$ & \\
\hline
\end{tabular}

Notes: *Pearson chi-squared test; **Mann-Whitney test. that the number of women at risk for death was 51, and the ratio was 11.2/1,000 LBs. - Table 2 shows the maternal outcomes of the women classified with severe maternal morbidity with and without hypertension.

Among the 10 cases of maternal death, all involved hospitalization in the ICU, and 7 patients received blood products. Among the cases with hypertensive syndromes, there were two cases of severe preeclampsia, and three of eclampsia. None of the patients with HELLP syndrome died. Sepsis was diagnosed in two of these cases. In the group without hypertension, four women died of hemorrhagic syndromes (two with premature placental detachment and two with a previous placenta accreta) and one case of severe sepsis was observed. Perinatal death was more prevalent in the group without hypertension $(19.8 \%$ versus $5 \%, p<0.001)$ (-Table 3).

No significant differences in the near miss criteria between the participants with and without hypertensive disorders were observed, except for cyanosis (72\% versus $28 \%$, $p=0.038$ ) and cardiopulmonary resuscitation (76\% versus $24 \%, p=0.011)$, which were more prevalent in the group with hypertension (- Table 4).

\section{Discussion}

The present study evaluated severe maternal morbidity/ maternal near miss in women with or without hypertension during pregnancy. It was performed in a reference center for obstetric and neonatal care over one year. We observed the presence of hypertension in most the participants (89.1\%) who met the severe criteria.

Hypertensive syndromes are widely understood as the main cause of complications in prenatal care, occurring in $2 \%$ to $26 \%$ of gestations. ${ }^{16,17}$ Hypertensive disorders are responsible for nearly 45,000 cases of maternal death every year worldwide, and are the main cause of maternal health in Latina America and the Caribbean. Estimates indicate that this problem represents a quarter of the total number of these deaths. ${ }^{7,8}$ These observations make the study of the incidence of hypertension and its related causes relevant to understanding its relationship with maternal near miss.

Vidal et al $^{18}$ performed a study whose goal was to identify the factors associated with maternal near miss in the city of Barbacena, state of Minas Gerais, Brazil. This study identified that in a sample of 276 women, which included 92 cases and 184 controls, the parturient women with a previous history of hypertension had a greater risk of developing severe maternal morbidity, such as preeclampsia and HELLP syndrome. In this group, $10.1 \%$ had severe hypertension, followed by $9.4 \%$ with severe preeclampsia, $0.4 \%$ with severe preeclampsia and severe hypertension, and $0.4 \%$ with eclampsia.

Studies point to hypertensive syndromes as frequent causes related to maternal near miss. In a study by Souza et $\mathrm{al}^{19} 57 \%$ of the women had hypertensive disorders. In a study by Morse et al, ${ }^{20}$, nearly $70 \%$ of the women had preeclampsia, HELPP syndrome and eclampsia. This evidence emphasizes the need for and importance of prevention, early detection and treatment of these complications to control 
Table 4 Maternal near miss criteria among the participants with and without hypertensive disorders

\begin{tabular}{|c|c|c|c|}
\hline \multirow[b]{2}{*}{ Clinical criteria } & \multicolumn{3}{|c|}{ Hypertension } \\
\hline & $\begin{array}{l}\text { Yes } \\
\text { n (\%) }\end{array}$ & $\begin{array}{l}\text { No } \\
\text { n (\%) }\end{array}$ & $p$-value \\
\hline Acute cyanosis & $20(72)$ & $8(28)$ & $0.038^{*}$ \\
\hline Respiratory rate $>40$ or $<60 \mathrm{bpm}$ & $16(70)$ & $7(30)$ & $0.542^{*}$ \\
\hline Oliguria unresponsive to fluids and diuretics & $19(66)$ & $8(34)$ & $0.197^{*}$ \\
\hline Shock & $18(75)$ & $6(25)$ & $0.053^{*}$ \\
\hline Coagulation disorders & $20(71)$ & $8(29)$ & $0.038^{*}$ \\
\hline Loss of consciousness for 12 hours or more & $13(62)$ & $8(38)$ & $0.398^{*}$ \\
\hline Absence of consciousness and absence of pulsations or cardiac beats & $15(62)$ & $9(38)$ & $0.333^{*}$ \\
\hline Cerebrovascular accident & $17(65)$ & $9(35)$ & $0.704^{*}$ \\
\hline Uncontrolled convulsion & $16(62)$ & $10(38)$ & $0.129^{*}$ \\
\hline Jaundice in the presence of preeclampsia & $18(64)$ & $10(36)$ & $0.301^{*}$ \\
\hline \multicolumn{4}{|l|}{ Laboratorial criteria } \\
\hline Saturation and oxygen $<90 \%$ for 60 minutes or more & $18(67)$ & $9(33)$ & $0.516^{*}$ \\
\hline $\mathrm{PaO}_{2} / \mathrm{FiO}_{2}<200 \mathrm{~mm} \mathrm{Hg}$ & $18(67)$ & $9(33)$ & $0.516^{*}$ \\
\hline Creatine $\geq 3.5 \mathrm{~mm} \mathrm{Hg} / \mathrm{dL}$ or $\geq 300 \mu \mathrm{Mol} / 1$ & $18(67)$ & $9(33)$ & $0.516^{*}$ \\
\hline Bilirubin $\geq 6.0 \mathrm{mg} / \mathrm{dL}$ or $>100 \mu \mathrm{Mol} / 1$ & $15(60)$ & $10(40)$ & $0.283^{*}$ \\
\hline $\mathrm{pH}<7,1$ & $20(65)$ & $11(35)$ & $0.112^{*}$ \\
\hline Acute thrombopenia $\left(<50,000 / \mathrm{mm}^{3}\right)$ & $11(61)$ & $7(38)$ & $0.641^{*}$ \\
\hline \multicolumn{4}{|l|}{ Handling criteria } \\
\hline Continuous use of vasoactive drug & $12(75)$ & $4(25)$ & $0.515^{*}$ \\
\hline Puerperal hysterectomy by infection and hemorrhage & $23(70)$ & $10(30)$ & $0.882^{*}$ \\
\hline Transfusion $\geq 5$ units of red-blood cell concentrate & $22(76)$ & $7(24)$ & $0.127^{*}$ \\
\hline Intubation and ventilation for $\geq 60$ minutes not related to anesthesia & $13(76)$ & $4(24)$ & $0.389^{*}$ \\
\hline Dialysis for acute renal insufficiency & $26(76)$ & $8(24)$ & $0.011^{*}$ \\
\hline Cardiopulmonary resuscitation (CPR) & $21(70)$ & $9(30)$ & $0.849^{*}$ \\
\hline
\end{tabular}

Note: *Pearson chi-squared test.

and reduce the risk of maternal near miss related to hypertensive causes.

We found that a lower frequency of the subjects in this population group evolved to more severe cases, as a lower frequency of subjects who met the maternal near miss criteria and a lower frequency of maternal and perinatal deaths were observed when compared with cases who met the morbidity criteria that were not associated with hypertensive disorders.

A possible explanation for these findings is that, as the two groups (with and without hypertension) were epidemiologically similar, there may be differences in the expertise of the institution's clinical body in managing cases with gestational hypertensive syndromes. The assistance protocols, which are often updated and based on the available scientific evidence, are widely disseminated in written form in virtual environments and on banners in every maternity sector where patients with hypertensive complications are cared for.

There was a prioritization in recent years of the dissemination of knowledge on gestational hypertensive pathologies with the development of multiprofessional protocols adapted to local realities, because this is the most prevalent pathology in cases of perinatal and maternal deaths. The magnesium sulfate protocols were associated with improvements in maternal indicators, as they are widely known and often implemented when they are recommended, and they lead to lower lethality in these cases. It is important to note that MEAC-UFC is the main reference point for gestational complications in the state of Ceará, Brazil - with a profile of following risky pregnancies.

The results of the present study showed that the maternal near miss ratio was of 55.55/1,000 LBs. These data are compatible with those found in the literature, which range from 0.7 to 101.7 cases per 1,000 births. ${ }^{4,5,15}$ Souza et a ${ }^{19}$ performed a study with 2,929 women, and identified a severe maternal morbidity ratio from 15 to 42 cases/1,000 births. In the same study, the estimated near miss morbidity was of 44.3/1,000 LBs. It is important to point out that most studies work with the number of births in the denominator of the maternal morbidity ratio, whereas the WHO recommends using LBs, as we have done in our study. The mortality ratio in the maternal near miss cases was of $18 \%$, which is compatible with what is found in the literature $11,19-22$ for countries with low and medium socioeconomic levels. 
It is necessary to develop a public policy to protect maternal and child health throughout all of the care levels to prevent complications or evolution into severe cases. ${ }^{23} \mathrm{~A}$ severe problem associated with the development of complications and the evolution of severity in the puerperal pregnancy cycle are delays in obstetrical assistance, whether they are related to patients, families, access difficulties, inefficient referencecounter reference systems, or care units and their staff (late diagnosis, delay in the appropriate and timely establishment of a therapy). An explanatory model was described by Thaddeus and Maine in $1994 .^{24}$

Unfortunately, these delays were not evaluated in the present study, and they may explain the worse evolution and higher lethality found in the cases associated with hypertension when compared with the cases that did not show this association. Another cause of maternal morbidity/ mortality are hemorrhagic syndromes, in which little time is available to avoid more severe complications and maternal and perinatal deaths.

A high frequency of cesarean sections (nearly 81\%) was observed among our study participants. This result is similar to what was observed in other studies. ${ }^{20}$ It is assumed that this occurs due to the risk of complication in the clinical state of the patients.

In relation to prenatal care, most patients in the present study had fewer than six prenatal care visits. In a study by Mantel et $\mathrm{al}^{25}$ the authors identified that between $21 \%$ and $30 \%$ of the women had not even been examined once during their prenatal care. When considering the results, it is important to note the number of visits that these pregnant women had. According to the WHO, the appropriate number of prenatal visits should be equal to or greater than six; however, this number may be lower in low-risk patients. Nevertheless, adequate prenatal assistance enables the early detection of and intervention for gestational complications, and it is a fundamental tool in reducing the risk of stillbirths and problems during pregnancy. The lack or the inadequacy of prenatal care is contemplated in level 1 and level 2 delays by Thaddeus and Maine. ${ }^{24}$

Some limitations in the present study must be recognized. The study was performed in a single unit; however, the maternity school is a reference for third-level care, and the sampling involved a significant number of patients. Another limitation was that the data were collected from records without applying a direct contact tool with the women, which could have broadened the range of information, such as information related to prenatal care and delays in the path through the health system when a patient needs hospital and medical care. We suggest that this tool be used in further studies.

The main limitation of the study is that the data collection period took place $\sim 9$ years ago; however, data on near miss and maternal morbidity in the institution are now presented annually as a management report, and are very similar to those data that were collected. Additionally, these data were collected with a rigorous methodology, and were approved by the ethics committee for collection and therefore publication. These were factors for us in reporting this longstanding data.
The data found here have the potential to aid in the surveillance of maternal near miss cases and risk factors. They point out the importance of adequate prenatal care and assistance, as they present a determining factor in the reduction of the risk of hypertensive complications and subsequent cases of maternal near miss, which could be avoided.

\section{Conclusion}

In summary, in the severe morbidity/maternal near miss population, the presence of hypertensive complications was very prevalent, constituting a risk factor for pregnant women and their fetuses. Among the women with hypertensive syndromes, we observed a lower presence of maternal near miss criteria and lower maternal and perinatal mortality rates when compared with women without hypertensive problems.

\section{Contributors}

All of the authors contributed with the project and data interpretation, the writing of the article, the critical review of the intellectual content, and with the final approval of the version to be published.

\section{Conflict of Interests}

The authors have no conflict of interests to declare.

\section{References}

1 Antza C, Cifkova R, Kotsis V. Hypertensive complications of pregnancy: A clinical overview. Metabolism 2018;86:102-111. Doi: 10.1016/j.metabol.2017.11.011

2 Mbachu II, Udigwe GO, Okafor CI, Umeonunihu OS, Ezeama C, Eleje GU. The pattern and obstetric outcome of hypertensive disorders of pregnancy in Nnewi, Nigeria. Niger J Med 2013;22 (02):117-122

3 Ye C, Ruan Y, Zou L, Li G, Li C, Chen Y, et al. The 2011 survey on hypertensive disorders of pregnancy (HDP) in China: prevalence, risk factors, complications, pregnancy and perinatal outcomes. PLoS One 2014;9(06):e100180. Doi: 10.1371/journal. pone. 0100180

4 Shah S, Gupta A. Hypertensive disorders of pregnancy. Cardiol Clin 2019;37(03):345-354. Doi: 10.1016/j.ccl.2019.04.008

5 Sutton ALM, Harper LM, Tita ATN. Hypertensive disorders in pregnancy. Obstet Gynecol Clin North Am 2018;45(02): 333-347. Doi: 10.1016/j.ogc.2018.01.012

6 Brown MA, Magee LA, Kenny LC, Karumanchi SA, McCarthy FP, Saito $S$, et al. International Society for the Study of Hypertension in Pregnancy (ISSHP). The hypertensive disorders of pregnancy: ISSHP classification, diagnosis \& management recommendations for international practice. Pregnancy Hypertens 2018;13:291-310. Doi: 10.1016/j.preghy.2018.05.004

7 Say L, Chou D, Gemmill A, Tunçalp Ö, Moller AB, Daniels J, et al. Global causes of maternal death: a WHO systematic analysis. Lancet Glob Health 2014;2(06):e323-e333. Doi: 10.1016/S2214109X(14)70227-X

8 Alkema L, Chou D, Hogan D, Zhang S, Moller AB, Gemmill A, et al. United Nations Maternal Mortality Estimation Inter-Agency Group collaborators and technical advisory group. Global, region$\mathrm{al}$, and national levels and trends in maternal mortality between 1990 and 2015, with scenario-based projections to 2030: a systematic analysis by the UN Maternal Mortality Estimation 
Inter-Agency Group. Lancet 2016;387(10017):462-474. Doi: 10.1016/S0140-6736(15)00838-7

9 Zanette E, Parpinelli MA, Surita FG, Costa ML, Haddad SM, Sousa $\mathrm{MH}$, et al. Brazilian Network for Surveillance of Severe Maternal Morbidity Group. Maternal near miss and death among women with severe hypertensive disorders: a Brazilian multicenter surveillance study. Reprod Health 2014;11(01):4. Doi: 10.1186/ 1742-4755-11-4

10 Bandali S, Thomas C, Hukin E, Matthews Z, Mathai M, Ramachandran Dilip T, et al. Maternal Death Surveillance and Response Systems in driving accountability and influencing change. Int J Gynaecol Obstet 2016;135(03):365-371. Doi: 10.1016/j.ijgo.2016.10.002

11 Smith H, Ameh C, Roos N, Mathai M, Broek NVD. Implementing maternal death surveillance and response: a review of lessons from country case studies. BMC Pregnancy Childbirth 2017;17 (01):233. Doi: 10.1186/s12884-017-1405-6

12 Souza JP, Gülmezoglu AM, Carroli G, Lumbiganon P, Qureshi Z; WHOMCS Research Group. The world health organization multicountry survey on maternal and newborn health: study protocol. BMC Health Serv Res 2011;11:286. Doi: 10.1186/1472-6963-11286

13 Souza JP, Cecatti JG, Haddad SM, Parpinelli MA, Costa ML, Katz L, et al. Brazilian Network for Surveillance of Severe Maternal Morbidity Group; Brazilian Network for Surveillance of Severe Maternal Morbidity. The WHO maternal near-miss approach and the maternal severity index model (MSI): tools for assessing the management of severe maternal morbidity. PLoS One 2012;7(08): e44129. Doi: 10.1371/journal.pone.0044129

14 Say L, Souza JP, Pattinson RC; WHO working group on Maternal Mortality and Morbidity classifications. Maternal near misstowards a standard tool for monitoring quality of maternal health care. Best Pract Res Clin Obstet Gynaecol 2009;23(03):287-296. Doi: 10.1016/j.bpobgyn.2009.01.007

15 Cecatti JG, Souza JP, Parpinelli MA, Haddad SM, Camargo RS, Pacagnella RC, et al. Brazilian Network for Surveillance of Severe Maternal Morbidity. Brazilian network for the surveillance of maternal potentially life threatening morbidity and maternal near-miss and a multidimensional evaluation of their long term consequences. Reprod Health 2009;6:15. Doi: 10.1186/17424755-6-15
16 Tranquilli AL, Dekker G, Magee L, Roberts J, Sibai BM, Steyn W, et al. The classification, diagnosis and management of the hypertensive disorders of pregnancy: A revised statement from the ISSHP. Pregnancy Hypertens 2014;4(02):97-104. Doi: 10.1016/j. preghy.2014.02.001

17 ACOG Practice Bulletin No. 202: Gestational Hypertension and Preeclampsia. Obstet Gynecol 2019;133(01):e1-e25. Doi: 10.1097/AOG.0000000000003018

18 Vidal CE, Carvalho MAB, Grimaldi IR, Reis MC, Baêta MCN, Garcia $\mathrm{RB}$, et al. [Severe maternal morbidity in the microregion of Barbacena, Minas Gerais state, Brazil]. Cad Saude Colet 2016;24 (02):131-138. Doi: 10.1590/1414-462X201600020181

19 Souza JP, Cecatti JG, Parpinelli MA, Serruya SJ, Amaral E. Appropriate criteria for identification of near-miss maternal morbidity in tertiary care facilities: a cross sectional study. BMC Pregnancy Childbirth 2007;7:20. Doi: 10.1186/1471-2393-7-20

20 Morse ML, Fonseca SC, Gottgtroy CL, Waldmann CS, Gueller E. Severe maternal morbidity and near misses in a regional reference hospital. Rev Bras Epidemiol 2011;14(02):310-322. Doi: 10.1590/s1415-790X2011000200012

21 Lima HM, Carvalho FH, Feitosa FE, Nunes GC. Factors associated with maternal mortality among patients meeting criteria of severe maternal morbidity and near miss. Int J Gynaecol Obstet 2017;136(03):337-343. Doi: 10.1002/ijgo.12077

22 Vogel JP, Souza JP, Mori R, Morisaki N, Lumbiganon P, Laopaiboon M, et al. WHO Multicountry Survey on Maternal and Newborn Health Research Network. Maternal complications and perinatal mortality: findings of the World Health Organization Multicountry Survey on Maternal and Newborn Health. BJOG 2014;121 (Suppl 1):76-88. Doi: 10.1111/1471-0528.12633

23 Luz BG, Soares LT, Grillo VT, Viola BM, Laporte IC, Bino DB, et al. [The profile of high risk pregnant women a clinic of Divinópolis, in Minas Gerais, Brazil, in the biennium 2013/14.J Health Biol Sci 2015;3(03): 137-143. Doi: 10.12662/2317-3076jhbs.v3i3.177.p137-143.2015

24 Thaddeus S, Maine D. Too far to walk: maternal mortality in context. Soc Sci Med 1994;38(08):1091-1110. Doi: 10.1016/ 0277-9536(94)90226-7

25 Mantel GD, Buchmann E, Rees H, Pattinson RC. Severe acute maternal morbidity: a pilot study of a definition for a near-miss. Br J Obstet Gynaecol 1998;105(09):985-990. Doi: 10.1111/j.14710528.1998.tb10262.x 